\title{
FAKTOR-FAKTOR YANG BERHUBUNGAN DENGAN KUALITAS KERJA PETUGAS PEMBERANTASAN PENYAKIT DIARE
}

\author{
Mohammad Sadli*, Wawan Anwar K**
}

\begin{abstract}
ABSTRAK
Dari data laporan yang dilaporkan oleh seluruh puskesmas angka kesakitan diare sebanyak 28648 penderita dengan golongan umur < 1 Tahun : 4316 penderita, 1 - 4 Tahun : 8703 Penderita , > 5 Tahun : 15196 penderita. Masih tingginya angka incident diare di Kabupaten Cirebon. Tujuan penelitian ini untuk mengetahui faktorfaktor yang berhubungan dengan kualitas kerja petugas pemberantasan penyakit diare. Penelitian ini adalah jenis penelitian Analitik deskriptif dengan menggunakan desain penelitian cross sectional yaitu mempelajari semua individu yang berada taraf umurnya dan titik waktu yang sama atau pendekatan yang sifatnya sesaat pada satu waktu dan tidak diikuti dalam kurun waktu tertentu.yang menggambarkan tentang pelaksanaan program pemberantasan penyakit diare serta faktor-faktor yang mempengaruhi kualitas kerja petugas P2 Diare yang berhubungan dengan pelaksanaan program pemberantasan penyakit diare. Dalam penelitian ini, populasi adalah semua petugas P2 Diare di 37 Puskesmas yang ada di Kabupaten Cirebon. Besar sempel adalah sebesar 37 orang petugas P2 Diare di wilayah Dinas Kesehatan Kabupaten Cirebon yang diambil secara keseluruhan.Hasil Penelitian menujukan bahwa dari hasil uji statistik diketahui P Value pendidikan 0.928 dan 0.100 untuk pelatihan dengan $\alpha=0.05$ maka Pvalue $>\alpha$ menujukkan bahwa kedua faktor tersebut tidak ada hubungan dengan kualitas kerja petugas diare Puskesmas, menujukan bahwa P Value Keterampilan 0.568, dan Monev 0.121, ternyata untuk keterampilan dan monev Pvalue $>\alpha(0.05)$, maka tidak terdapat hubungan faktor keterampiian dan monev dengan kualitas kerja petugas Diare puskesmas.Sedangkan untuk keterampilan walaupun tidak terdapat hubungan yang erat namun ada kecendrungan dalam memberikan pengaruh terhadap kuaiitas kerja hal ini dapat dilihat dari adanya kenaikan rata-rata sebesar 0.31 poin, menunjukan bahwa $\mathrm{P}$ value sarana yang tersedia 0.019, Kepemimpinan 0.037 ternyata untuk Sarana dan kepemimpinan P value $<\alpha(0.05)$ maka terdapat hubungan antara faktor sarana dan kepemimpinan dengan kualitas kerja petugas Diare Puskesmas.
\end{abstract}

Kata Kunci : Kualitas Kerja, Pemberantasan Penyakit Diare

\section{ABSTRACT}

From the report data reported by all health centers diarrhea morbidityas as 28648 patients with go (Onganaged<1 Year: 4316 Patients, 1-4 years: 8703 patients, > 5 Years: 15196 patients. Stillhigh number ofincidents of diarrheain Cirebon. The purpose of this study was to determine the factors associated with quality work diarrheal desease control officer. Thisstudyis adescriptivetype of research Analytical using cross-sectional research designis to learnall the individuals who are ageleveland the same time point orapproach that character for a momentat a time and not followed within. describethe implementation of diarrheal disease eradication programand the factors that affect the quality of work P2 officer diarrhea associated with diarrheal disease control program implementation. In this study, the population is all Diarrhoea P2 officersin 37 health centers in Cirebon. Sampel large amount P2 Diarrhea 37 officersin The District Health Office Cirebon takenas a whole. Research address ingthat of the statistical test known Pvalue education 0928 and 0100 for training with $\alpha=0.05$ then the PValue $>\alpha$ address that both factors had no connection withthe workquality of PHC diarrhea officer, directing that Pvalue Skills 0568, and M \& E 0121, turned outto skills and M \& E Pvalue $>\alpha(0.05)$, then there is no relationship keterampilan factors and monitoring and evaluation officer with quality work Diarrhea clinic.As for skills although there is noclose relationship, but there isa tendency to give effect to work quality this can be seen from the average increase of 0.31 points, showed that Pvalue meansavailable 0019, 0037 Leadership and leadership turns outto Suppor the Pvalue $<\alpha(0.05)$ then there is acorrelation between the means and leadership with quality work Diarrhea health center personnel.

Keywords: Quality of Work, Diarrhea Disease Implementation

\footnotetext{
* Staf Pengajar Program Studi S1 Kesehatan Masyarakat STIKes Cirebon

** Alumni PSKM STIKes Cirebon Lulus Tahun 2014
} 


\section{PENDAHULUAN}

Penyakit Diare masih merupakan masalah kesehatan masyarakat di Indonesia, beberapa faktor yang menjadi penyebab timbulnya penyakit diare disebabkan oleh kuman melalui kontaminasi makanan/minuman yang tercemar tinja dan kontak langsung dengan penderita , sedangkan faktor-faktor lainya meliputi faktor penjamu dan faktor lingkungan. Gambaran secara keseluruhan angka insiden penyakit diare di Indonesia selama kurun waktu lima tahun dari tahun 2009 sampai tahun 2013 adalah: pada tahun 2009 sebesar 10,7 per 1000, pada tahun 20106,7 per 1000, tahun 2011 sebesar 10,6 per 1000, tahun 2012 sebesar 0,6 per 1000 dan tahun 2013 sebesar 5,8 per $1000 .^{1}$

Program pemberantasan penyakit menular mempunyai peranan dalam menurunkan angka kesakitan dan kematian. Tujuan tersebut dapat dicapai dengan penerapan teknologi kesehatan secara tepat oleh petugas-petugas Kesehatan yang didukung peran serta aktif dari masyarakat. ${ }^{1}$

Penyakit diare di Kabupaten Cirebon masih merupakan masalah dari tahun ke tahun. Penyakit ini selalu ada dan dapat menimbulkan kejadian luar biasa, dan menyebabkan kematian.Pola kematian menurut penyakit, penyebab kematian pasien kunjungan di puskesmas Kabupaten Cirebon untuk semua golongan umur tidak ditemukan adanya angka kematian diare. $^{2}$

Dari data laporan yang dilaporkan oleh seluruh puskesmas angka kesakitan diare sebanyak 28648 penderita dengan go(ongan umur $<1$ Tahun:4316 penderita, 1 - 4 Tahun: 8703 Penderita, >5 Tahun:15196 penderita. Masih tingginya angka incident diare di Kabupaten Cirebon. Dengan demikian diharapkan penelitian ini dapat meningkatkan kemampuan petugas di dalam melakukan pengamatan, serta mengintensipkan dalam pelaksanaan system kewaspadaan dini atas kemungkinan terjadinya letusan kejadian luar biasa diare. $^{2}$

Berdasarkan data ketenagaan bahwa di setiap Puskesmas pelaksana Program P2 Diare dipegang oleh satu orang dengan kualifikasi pendidikan perawat kesehatan dan belum mendapat pelatihan, begitu juga dengan pelatihan kader belum dilaksanakan.

Sarana dan prasarana di tempat perawatan dan rawat jalan terdapat pojok URO tetapi belum semua puskesmas melaksanakannya begitu juga di tempat Puskesmas Pembantu dan Polindes., untuk kebutuhan oralit tidak sesuai dengan kebutuhan yang diperhitungkan sesuai dengan perkiraan target pelayanan penderita. Buku pedoman/petunjuk oprasional/bentuk terpadu lainnya belum ada edisi terbaru dan format/alat tulis kerja sebagai bahan administrasi dalam hal, pelaporan puskesmas mengadakan sendiri Begitu juga dukungan dana kurang berjalan. $^{2}$

Berdasarkan hal tersebut di atas penulis merasa tertarik untuk melakukan penelitian Tentang Faktor-Faktor yang berhubungan dengan kualitas kerja petugas program P2 Diare puskesmas di Kabupaten Cirebon.

\section{METODOLOGI PENELITIAN}

Penelitian ini adalah jenis penelitian Analitik deskriptif dengan menggunakan desain penelitian cross sectional. Dalam penelitian ini, populasi adalah semua petugas P2 Diare di 37 Puskesmas yang ada di Kabupaten Cirebon.

Besar sempel adalah sebesar 37 orang petugas P2 Diare di wilayah Dinas Kesehatan Kabupaten Cirebon yang diambil secara keseluruhan. Teknik analisa data sebagai berikut:

1. Analisa Univariat

Melakukan analisa data yang diperoleh dan disajikan dengan menggunakan table distribusi frekuensi dan menggunakan uji statistik (deskriptif yang sesuai). Pada 
analisa ini dapat dilihat karakteristik petugas P2 Diare puskesmas di Kabupaten Cirebon yang meliputi faktor internal dan faktor eksternal petugas Diare tersebut.

2. Analisa Bivariat

Untuk mengetahui adanya hubungan antara dua variable yaitu variable bebas terhadap variable dengan menggunakan perangkat lunak komputer. Uji yang digunakan adalah uji statistik T-tes independent yang diuji adalah:

1) Antara keterampilan dengan kualitas kerja petugas P2 diare dalam pelaksanaan program pemberantasan penyakit diare

2) Antara sarana yang tersedia dengan kualitas kerja petugas $P 2$ diare dalam pelaksanaan program pemberantasan penyakit diare

3) Antara kepemimpinan dengan kualitas kerja petugas P2 diare dalam pelaksanaan program pemberantasan penyakit diare

4) Antara Monitoring evaluasi dengan kualitas kerja petugas P2 diare dalam pelaksanaan program pemberantasan penyakit diare dengan Keputusan sebagai berikut :

(1)P value $\leq \alpha$, Ho ditolak yang berarti ada hubungan yang bermakna, dengan tingkat kemaknaan $95 \%(\alpha=0,05)$

(2)P value $>\alpha$, Ho gagal ditolak yang berarti tidak terdapat hubungan yang bermakna, dengan tingkat kemaknaan $95 \%(\alpha=0,05)$

Sedangkan untuk menguji :

1) Antara Pendidikan dengan kualitas kerja petugas $P 2$ diare dalam pelaksanaan program pemberantasan penyakit diare

2) Antara Pelatihan dengan kualitas kerja petugas P2 diare dalam pelaksanaan program pemberantasan penyakit diare adalah menggunakan uji statistik Anova dua arah dengan keputusan :

(1) $\mathrm{P}$ value $\leq \alpha$, Ho ditolak yang berarti ada hubungan yang bermakna, dengan tingkat kemaknaan $95 \%(\alpha=0,05)$

(2) $\mathrm{P}$ value $>\alpha$, Ho gagal ditolak yang berarti tidak terdapat hubungan yang bermakna, dengan tingkat kemaknaan $95 \%(\alpha=0,05)$

\section{HASIL PENELITIAN}

\section{Kualitas Kerja Petugas P2 Diare}

Hasil penelitian menujukkan bahwa lebih dari sebagian petugas Diare puskesmas memiliki kualitas kerja baik 23 responden $(62,2 \%)$.

\section{Pendidikan}

Hasil penelitian menunjukkan bahwa 94,6\% responden berpendidikan SPK/AKPER dan berpendidikan SKP/SKM 5,4\%

\section{Umur}

Hasil penelitian menunjukkan bahwa mayoritas umur petugas di Pepuskesmas tergalong muda yaitu 31 responden $(83.8 \%)$.

\section{Pelatihan}

Hasil penelitian menunjukkan bahwa ternyata hampir semua petugas diare tidak perna mendapatkan pelatihan diare 36 responden $(97,3 \%)$. 


\section{Keterampilan}

Hasil penelitian menujukkan bahwa hampir separuh petugas diare Puskesmas Terampil dalam pengelolaan program Diare 23 responden $(62.2 \%)$.

\section{Sarana yang tersedia}

Hasil penelitian menunjukkan bahwa sebagian besar puskesmas di Kabupaten Cirebon memiliki sarana pengelolaan program diare dengan lengkap 35 responden $(94.6 \%)$

\section{Kepemimpinan}

Hasil penelitian menujukkan bahwa sebagian besar kepala Puskesmas adanya kepemimpinan terhadap petugas Diare puskesmas 19 responden $(51.4 \%)$.

\section{Monitoring Evaluasi}

Hasil penelitian menujukkan bahwa sebagian besar petugas Kabupaten melakukan monitoring kepada petugas Diare Puskesmas 22 responden $(59.5 \%)$.

\section{Hubungan antara Pendidikan, Pelatihan dengan Kulitas kerja}

Tabel 1. Hubungan Faktor pendidikan, Pelatihan dengan Kualitas Kerja

\begin{tabular}{|c|c|c|c|}
\hline Faktor & Kategori & Mean rank & $\mathrm{P}$ value \\
\hline \multirow[t]{5}{*}{ Pendidikan } & SMU & 0 & 0.928 \\
\hline & SPK/AKPER & 13.4 & \\
\hline & SPPH/AKL & 0 & \\
\hline & SPAG/AKZI & 0 & \\
\hline & SKp/SKM & 13.5 & \\
\hline \multirow[t]{3}{*}{ Pelatihan } & Sering & 0 & 0.100 \\
\hline & Pernah & 11.00 & \\
\hline & Tidak pernah & 13.47 & \\
\hline
\end{tabular}

Dari tabel di atas menujukan bahwa dari hasil uji statistik diketahui PValue pendidikan 0.928 dan 0.100 untuk pelatihan dengan $\alpha=0.05$ maka PValue $>\alpha$ menujukan bahwa kedua faktor tersebut tidak ada hubungan dengan kualitas kerja petugas diare Puskesmas.

\section{Hubungan antara Keterampilan, dan Monitoring Evaluasi dengan Kualitas Kerja}

Tabel 2. Hubungan Faktor Keterampilan, dan Monitoring Evaluasi dengan Kualitas Kerja

\begin{tabular}{clllc}
\hline Faktor & \multicolumn{1}{c}{ Kategori } & Mean & SD & P Value \\
\hline \multirow{2}{*}{ Keterampilan } & Tampil & 13.52 & 1.37 & 0,568 \\
\cline { 2 - 4 } & Tdk. Terampil & 13.21 & 1.67 & \\
\hline \multirow{2}{*}{ Monev } & Ada & 13.10 & 1.44 & 0,121 \\
\cline { 2 - 4 } & Tdk. Ada & 13.87 & 1.45 & \\
\hline
\end{tabular}

Dari tabel di atas menujukan bahwa Pvalue Keterampilan 0.568, dan Monev 0.121, ternyata untuk keterampilan dan monev Pvalue $>\alpha(0.05)$, maka tidak terdapat hubungan faktor keterampilan dan monitoring dan evaluasi dengan kualitas kerja petugas Diare puskesmas, sedangkan untuk keterampilan walaupun tidak terdapat hubungan yang erat namun ada kecendrungan dalam memberikan pengaruh terhadap kuaiitas kerja hal ini dapat dilihat dari adanya kenaikan rata-rata sebesar 0.31 poin. 


\section{Hubungan antara sarana, dan kepemimpinan dengan Kualitas Kerja}

Tabel 3. Hubungan Faktor sarana, dan kepemimpinan dengan Kualitas Kerja

\begin{tabular}{clllc}
\hline Faktor & \multicolumn{1}{c}{ Kategori } & Mean & SD & P Value \\
\hline \multirow{2}{*}{ Sarana } & Tampil & 13.37 & 1.52 & 0.019 \\
\cline { 2 - 4 } & Tdk. Terampil & 14.00 & 0.00 & \\
\hline \multirow{2}{*}{ Kepemimpinan } & Ada & 13.89 & 1.37 & 0.037 \\
\cline { 2 - 4 } & Tdk. Ada & 12.89 & 1.45 & \\
\hline
\end{tabular}

Dari tabel di atas menunjukan bahwa Pvalue sarana yang tersedia 0.019, Kepemimpinan 0.037 ternyata untuk Sarana dan kepemimpinan Pvalue < $\alpha(0.05)$ maka terdapat hubungan antara faktor sarana dan kepemimpinan dengan kualitas kerja petugas Diare Puskesmas.

\section{PEMBAHASAN}

\section{Kualitas kerja petugas Diare Puskesmas}

Dalam penelitian yang dimaksud dengan kualitas kerja adalah penempilan kerja petugas diare puskesmas dalam program penanggulangan diare (Promotif, Prepentif, kuratif dan rehabilitatif). Diukur melalui observasi langsung oleh peneliti yang dilengkapi dengan kuesioner yang berisi pertanyaan rnemuat 8 pertanyaan/item. Pada masing-masing item diberi nilai 2 jika dilakukan dan nilai 1 jika tidak dilakukan, skor tersebut kemudian dijumlahkan dan jumlah tersebut tidak dikategorikan (Sebagai data continue).

\section{Hubungan Pendidikan dan Pelatihan dengan Kualitas Kerja}

Pada penelitian ini sebagian besar responden berpendidikan SPK/AKPER yaitu $94.6 \%$ dan sisanya berpendidikan SKp/SKM.Melalui uji statistik anova dengan tingkat kemaknaan $95 \%$ dan $\alpha=0,05$ didapat $\mathrm{P}$ value $>\alpha(0,05)$ terlihat tidak terdapat hubungan yang bermakna antara pendidikan dengan kualitas kerja petugas diare puskesmas, dengan demikian hipotesis tentang ada hubungan variabel pendidikan dengan kualitas kerja petugas diare puskesmas tidak terbukti, hasil ini sejalan dengan penelitian Pebriani (2041) yang menyatakan tidak ada hubungan variabel pendidikan terhadap kualitas kerja pembimbing praktek lapangan Akper.

Pelatihan merupakan bagian dari suatu proses pendidikan yang bertujuan untuk meningkatkan kemampuan atau keterampilan khusus seseorang atau kelompok orang. Pelatihan juga dapat merupakan cara untuk membekali tenaga kerja yang tidak mempunyai pendidikan formal sesuai tugasnya, sehingga meningkatkan kualitas kerjanya, dalam penelitian ini diharapkan agar seseorang lebih mudah melaksanakan tugasnya.

Hasil penelitian ini menunjukan bahwa sebagian besar responden tidak mendapatkan pelatihan, melaui uji statistik anova dengan tingkat kemaknaan $95 \% \alpha(0,05)$ di dapatkan $\mathrm{P}=$ 0.100 dengan demikian $\mathrm{P}$ value $>\alpha(0,05)$ artinya tidak terdapat hubungan yang bermakna antara variabel pelatihan dengan kualitas kerja petugas diare puskesmas. Hal tersebut berbeda dengan penelitian sebelumnya, missal Ilias (1998) menyatakan ada hubungan pelatihan saat tugas dengan kinerja dokter PTT di puskesmas. Akan tetapi penelitian yang dilakukan Basjuni (2001) sejalan dengan penelitian ini yaitu tidak ada hubungan antara pelatihan dengan kinerja petugas TB paru.

Tidak terdapat hubungan pelatihan dengan kualitas kerja ini kemungkinan disebabkan oleh materi dan metoda yang diberikan pada saat pelatihan belum sesuai dan bermanfaat bagi petugas. 


\section{Keterampilan}

Hasil penelitian menunjukan bahwa 23 responden $(62,2 \%)$ terampil dalam melaksanakan tugas penanggulangan diare, Kartzdan Mintzberg, 1984 berpendapat mengenai keterampilan teknis yaitu kemampuan menggunakan pengetahuan, alat, pmsedur, teknik dan metoda suatu bidang tertentu, dari data yang ada mayoritas responden adalah terampil.

Hasil uji statistik dengan menggunakan T-Test indefendent pada penelitian ini di dapat $\mathrm{P}$ $=0.568$ dengan $\alpha(0,45)$ maka Pvalue $>\alpha(0,05)$ yang artinya tidak terdapat hubungan antara keterampilan dengan kualitas kerja petugas diare puskesmas, akan tetapi ada kecendrungan dalam memberikan pengaruh terhadap kualitas kerja dengan dilihat adanya kenaikan rata-rata sebesar 0.31 poin.Hal ini bertolak belakang dengan penelitian sebelumnya A. Zaenudin (2004) yang menyatakan ada hubungan bermakna antara keterampilan dengan kualitas kerja petugas TB paru.

\section{Sarana yang tersedia dan Kepemimpinan}

Sumber daya merupakan bagian atau elemen dari input, keberadaan sumber daya dalam suatu organisasi merupakan hal yang paling pokak sekaligus sebagai modal dasar untuk berfungsinya suatu organisasi. Puskesmas sebagai salah satu organisasi fungsional yang menghasilkan jasa pelayanan Kesehatan, memiliki sumberdaya yang mencakup ketenagaan, dana, sarana dan metoda. ${ }^{4}$

Hasil penelitian menunjukan bahwa responden yang memiliki sarana lengkap sebesar 94,6 $\%$. Dari hasil uju statistik menggunakan T-Test Indefendent didapatkan $\mathrm{P}=0.019$ dengan $\alpha$ $(0,05)$ maka Pvalue $<\alpha(0,05)$ yang artinya terdapat hubungan yang bermakna antara sarana yang tersedia dengan kualitas kerja petugas diare puskesmas. Hal ini sesuai dengan penelitian A. Zaenudin, 2004 yang menyatakan bahwa ada hubungan yang bermakna antara sarana dengan kualitas kerja petyugas TB paru.

\section{Kepemimpinan}

Kepemimpinan adalah kempampuan untuk mempengaruhi suatu kelompok ke arah tercapainya tujuan. ${ }^{5}$ Dari hasil analisis univariat didapat dari 37 responden lebih banyak menilai kepemimpinan oleh kepala puskesmas baik yaitu $51.4 \%$, dari hasil uji statistik T-Test indefendent terdapat hubungan yang bermakna antara kepemimpinan dengan kualitas kerja petugas diare puskesmas dengan $\mathrm{P}=0.037 \alpha(0,05)(\mathrm{P}$ value $<\alpha(0,05)$. Hasil tersebut sesuai dengan Gibson, bahwa ada hubungan antara faktor kepemimpinan dengan Kinerja. ${ }^{6}$

Dengan demikian hipotesis tentang adanya hubungan antara faktor kepemimpinan dengan kualitas kerja petugas diare terbukti bermakna secara statistik.

\section{Monitoring evaluasi}

Monitoring evaluasi merupakan suatu kegiatan pembinaan, bimbingan dan pengawasan oleh pengelola program/proyek terhadap pelaksanaan program di tingkat administrative yang lebih rendah, tujuan dari monev adalah mengatasi masalah yang dihadapi petugas dilapangan untuk meningkatkan pengetahuan dan keterampilan petugas yang di monev dalam rangka memotivasi kerja petugas. ${ }^{1}$ Dalam penelitian ini $59.5 \%$ mendapatkan monitoring evaluasi, dari hasil uji statistik didapatkan tidak ada hubungan yang bermakna antara faktor monitoring evaluasi dengan kualitas kerja petugas diare puskesmas dengan $\mathrm{P}=0.121$ dan a yang digunakan 0.05 (Pvalue $>\alpha$ 0,05).Hal ini tidak sesuai dengan penelitian Rumisis (2003) bahwa monev bermanfaat berpeluang 5.192 kali meningkatkan kinerja bidan didesa.Pada 
penelitian ini hipotesis yang diduga ada hubungan yang bermakna antara faktor Monev dengan kualitas kerja petugas diare tidak terbukti.

\section{SIMPULAN}

Berdasarkan hasil analisis data dan pembahasan tentang faktor-faktor yang berhubungan dengan kualitas kerja petugas diare puskesmas di Kabupaten Cirebon dapat ditarik kesimpulan sebagai berikut :

1. Lebih dari setengah petugas diare puskesmas menunjukan kualitas kerja yang baik.

2. Ada hubungan yang bermakna antara sarana yang tersedia dengan kualitas kerja petugas diare puskesmas. Dengan P value yang didapat sebesar 0.019 dengan $\alpha(0,05)$

3. Ada hubungan yang bermakna antara faktor kepemimpinan dengan kualitas kerja petugas diare puskesmas.

4. Tidak ada hubungan yang bermakna antara faktor pendidikan dengan kualitas petugas diare puskesmas.

5. Tidak ada hubungan antara faktor pelatihan dengan kualitas kerja petugas diare puskesmas.

6. Tidak ada hubungan antara faktor keterampilan dengan kualitas kerja petugas diare puskesmas

7. Tidak ada hubungan antara faktor monitoring evaluasi dengan kualitas kerja petugas diare

\section{SARAN}

Berdasarkan kesimpulan penelitian tersebut di atas, dapat diajukan saran-saran sebagai berikut :

1. Bagi Dinas Kesehatan

1) Mengadakan pendidikan pelatihan bagi petugas diare puskesmas dengan materi mengenai manajemen mutu terpadu dalam menjalankan organisasi

2) Melakukan pembinaan melalui monitoring evaluasi kualitas kerja pada petugas diare puskesmas.

3) Menyediakan sarana dan prasarana bagi puskesmas yang belum lengkap.

2. Bagi UPTD Puskemas

1) Kepala Puskesmas hendak nya pada saat ini melakukan dan menerapkan kepemimpinan dengan prinsip dan fokus terhadap pelanggan baik pelanggan internal maupun ekternal

2) Puskesmas mulai mengoptimalkan segala sumber daya yang dimiliki dengan menjaga mutu pelayanan Kesehatan dengan melakukan paradigma sehat, pemeriksaan penunjang, diagnosa, terapi, perawatan atau konsultasi dan rujukan serta pencatatan dan pelaporan dengan mengacu pada standard an prosedur yang ditetapkan secara propesional.

3. Bagi Petugas Diare Puskesmas

Melakukan perbaikan kualitas kerja secara terus menerus dengan bertahap yang menggunakan sistem PDCA (plan, Do, Check, Action) dengan membuat suatu perencanaan yang baik dan pelaksanaan yang terpadu serta evaluasi secara terus menerus yang diintegrasikan dengan lintas program atau lintas sektoral.

\section{DAFTAR PUSTAKA}

1. Anonim. Buku Data Suveilan Epidemiologi, Jakarta: Departemen Kesehatan RI;2013

2. Anonim. Pedoman Pemberantasan Penyakif Diare,Jakarta :Depkes RI;2013

3. Anonim. Laporan Tahunan Dinas Kesehatan Kabupaten Cirebon, Cirebon: Dinkes Kab. Cirebon;2013 
4. Aditama Chandra Yoga.Manajemen Administrasi rumah Sakit:Jakarta;UI Press:2000

5. Gibson, James L.,Jhon M. Ivancevich dan James H. Donnelly, Jr., Organisasi : Perilaku, Strutur, Proses, Edisi Bahasa Indonesia, Alih bahasa oleh : Drs. Djarkasih, MPA., Edisi ke lima, Gelora Aksara Pratama;1996

6. Robbins, S.P., Perilaku Organisasi : Konsep, kontroversi,Aplikasi, Edisi ke Delapan, Jilid 1 dan 2, alih bahasa oleh : Agus Widiantoro.Jakarta: Pearson Education Asia Pte. Ltd. Dan PT. Pren halindo;2002 